\title{
Actualization of PPKn Learning Through Image Media on Pandemy Covid 19
}

\author{
S Suyahman \\ Lecturer of the PPKn Study Program \\ Faculty of Teacher Training and Education \\ Universitas Veteran Bangun Nusantara Sukoharjo \\ suyahman.suyahman@yahoo.com
}

\begin{abstract}
This study aims to describe the actualization of PPKn learning through image media in the Covid 19 pandemic. This type of research is qualitative research. The research subjects were teachers and grade VII students at SMP Negeri 1 Kartasura, and the objects were the actualization of PPKn learning and image media. Data collection methods Interview, questionnaire and documentation. The data validity was done by triangulating sources and methods. The data analysis technique was carried out using interactive analysis techniques consisting of 3 steps, namely: data reduction, data display and data verification. The results of the study were based on the results of interviews with 4 PPKn teachers conducted with Google Form, it was found that learning using image media could actualize the subject matter so that PPKn learning could be easily understood and absorbed by students. Likewise, the results of interviews with 32 students conducted using google form obtained information that PPKn learning using image media was very interesting and the material was easy to understand by looking at image media that clearly depicted teaching materials learned through google classroom. The conclusion based on the research results can be concluded that the image media can be used to actualize PPKn learning for grade VII students at SMP Negeri 1 Kartasura. With the PPKn learning image media can be interesting and can easily be understood by students.
\end{abstract}

Keywords: actualization of PPKn learning and image media

\section{Introduction}

According to Sarjono (2018) Learning is a process of teaching and learning activities that also plays a role in determining student success. (1) According to Ahmad Johari, 2008, from the learning process there will be a reciprocal activity between the teacher and students to get to a better goal. (2). Meanwhile, Tanto Praptomo (2020) explains that learning is a process of conveying information or knowledge from a teacher to students. (3) The concept of learning according to Sagala, Syaiful. 2003, is a process in which a person's environment is deliberately managed to allow him to participate in certain behavior under special conditions or to produce a response to certain situations, learning is a special subset of education. (4) Meanwhile, according to Hamalik (1994) is an effort organize an environment to create learning conditions for learners. (5) According to Law Number 20 of 2003, Learning is a process of interaction between students and educators and learning resources in a learning environment (6).

Departing from some of the limitations of learning above, it can be concluded that learning is the core of the overall educational process with educators as the main role holder, and is supported by students, facilities and infrastructure, teaching materials, methods, strategies, media and evaluation. The learning process is not just a transfer of knowledge but also ttitudes 
and skills. According to Miarso (2008: 30), in learning there are five types of interactions that can take place in the learning process, namely: 1) Interaction between educators and students 2) Interaction between fellow students 3) Interaction of students and resource persons 4) Interaction of participants students with educators with learning resources that are deliberately developed, and 5) The interaction of students with educators with the social and natural environment. (7)

Every learning process in a subject has characteristics that are different from one another. For example, the PPKn learning process according to the 2013 national curriculum puts forward the aspects of attitudes and skills without overriding the aspects of knowledge. PPKn learning requires teachers to target what character values to achieve in each learning process.

PPKn learning must not be verbalistic, meaning that students only know the words but do not understand the real meaning. (8) Therefore, PPKn teachers are required to be able to actualize learning material, so that the material is easily understood and absorbed by students. Efforts to do this can be done in various ways, including by selecting a media that is in accordance with the material being taught.

In this study, the material taught is Pancasila values which in the learning process is carried out online or online. The teacher must try to explain the material by using the right choice of media. According to researchers, the right media to help clarify the values of Pancasila is the image media. With picture media the teacher can explain easily: 1) actualization of the first Pancasila precepts, for example with pictures of places of worship for all religions in Indonesia, pictures of cleaning places of worship, images of religious tolerance, 2) actualizing the value of the second Pancasila precepts: for example with pictures of blood donors, visiting a sick friend, a picture of visiting an orphanage, a picture of crossing parents on the highway, 3) actualizing the value of the third Pancasila precept, for example the picture of taking part in eradicating people from drinking alcohol, pictures of people separating their friends from fighting, pictures of people wearing their own traditional clothes, 4) actualization of the fourth Pancasila precepts, for example a picture of the process for selecting class leaders, the Pilkades process, the process 1. elections, as well as pictures of deliberations in the family, and 5) actualization of the fifth Pancasila precepts, for example: pictures of dividing class cleanliness assignments fairly, pictures of providing natural disaster assistance fairly. (9)

In the Covid 19 pandemic situation, PPKn learning has many problems including: facilities and infrastructure problems such as cellphones, computers, application problems, pulse problems, signal problems, IT understanding limitations, and so on. Many of these problems make it a challenge for teachers, students and parents. Because it is necessary to find a solution to minimize the existing problems.

The ways that teachers can do include using applications that are easily understood by students, including by SMS, WA, contact person and video calls. In order to save on the cost of pulses, for contact person and video calls, efforts are made to a minimum, otherwise for SMS and WA, try as much as possible. To reduce the burden on students, it is better if the teacher gives assignments not too much, meaning that every time you meet online, you don't have to always be given assignments, so students have the opportunity to think and rest.

Based on the conception of learning, PPKn learning and the Covid 19 pandemic situation, this study focuses on how to create PPKn learning for grade VII students at SMP Negeri 1 Kartasura in the era of the Covid 19 pandemic which remains interesting, fun and excites students. In order to create PPKn learning for grade VII students at SMP Negeri 1 Kartasura in the Covid 19 pandemic era, it was carried out by actualizing PPKn learning which was supported by image media. 
Based on the preliminary description above, the main problem can be formulated: how to actualize PPKn learning through image media in the COVID-19 pandemic for grade VII students at SMP Negeri 1 Kartasura in the 2019-2020 academic year? And the research objective is to describe the actualization of PPKn learning through image media in the COVID-19 pandemic.

\section{Method}

The method used in this research is descriptive research method with a qualitative approach. Because basically want to understand and express in depth or according to the language of the researcher, namely describing the actualization of PPKn learning through the media of pictures on the COVID-19 pandemic for seventh grade students at SMP Negeri 1 Kartasura in the 2019-2020 academic year.

The research focus according to Sugiyono (2016: 286) states that focus is a single domain or several related domains of social situations. (10) In accordance with this research, the researcher determined the focus of the research based on the value of the findings and based on the problems related to theory and informants, namely: The importance of PPKn learning for class VII students who are interesting, fun and exciting, There is an assumption that the PPKn subject is less important then students pay less attention, conventional PPKn learning is carried out by teachers because the media is less attractive to students, there is a new paradigm of learning PPKn from offline to online.To solve the problem in this research, the required data is actualization data of PPKn learning. For this data obtained by using the interview method with teachers and students using an interview guide instrument. The applications used are WA and contact person. The data that was extracted was painful about how the implementation of PPKn learning is interesting, not fun, not exciting, if not what is the cause, whether the teacher, the method, the strategy, the teacher's appearance or the medium.

Then the other data required is the image media data. The method used to explore the image media data was interviews with teachers and students, the instruments used were interview guidelines. The applications used are WA and contact person. The question posed is how is the PPKn learning using picture media, can it clarify the subject matter, in your opinion the pictures used by the teacher are in accordance with the lesson ammunition presented or not, the pictures are colored or not, the pictures are large enough or not, and the pictures are interesting or not. In addition to these two data, the researcher also explores the understanding of the COVID-19 pandemic era. The questions asked whether online learning has difficulties, what kinds of difficulties, in your opinion, are face-to-face learning online. After the 3 data were obtained, data analysis was carried out using interactive qualitative analysis techniques consisting of data reduction, data display and data verification (11).

\section{Research Results and Discussion}

\subsection{Research result}

Based on the results of research obtained through interviews with the WA application and Contac Person with 5 PPKn teachers that the researchers conducted on March 6-7 2020, information was obtained that: Actualization of PPKn learning is very helpful in clarifying the 
teaching materials delivered to students, PPKn learning is very interactive and communicative, students feel very enjoyed and feel comfortable, actualization using image media is very beneficial, image media is very interesting because it is colorful and in accordance with the material presented by the teacher online.

Data from interviews with students conducted with WA and Contac person conducted by researchers on March 15-20 2020 obtained information: the image media is good and in accordance with the teaching material submitted by the teacher, the image media really clarifies the teaching materials submitted by the teacher, students very interested and enjoy learning comfortably.

Likewise, data from interviews with teachers and students about understanding PPKn learning online conducted by researchers using the WA application and ccontac person on March 21-25, 2020 obtained information; that online learning causes many problems for both teachers and students. Some of the problems faced are problems with facilities and infrastructure, signal problems, credit problems, application problems, and problems with IT understanding. Another problem is the reduced social interaction between students and their friends, students lose their world because of their limited interaction with their friends. With these various problems, the teacher is obliged to create creative and innovative learning so that the subject matter is easily understood and absorbed by students. One of the efforts that can be made by the teacher is to actualize PPKn learning which is supported by image media.

\subsection{Discussion}

The PPKn course aims to produce students who have faith and noble morals as directed by the philosophy of life of the Indonesian nation, namely Pancasila so that they can play a role as effective and responsible citizens. Menurt Saputro, 2014, the scope of PPKn SMP material includes four national consensus that are related to one another, namely Pancasila, the 1945 Constitution, the Unitary State of the Republic of Indonesia (NKRI), and Bhinneka Tunggal Ika (12)

The implementation of the 2013 curriculum for Pancasila and Citizenship Education (PPKn) learning management refers to the education process standards that have been regulated in the Regulation of the Minister of Education and Culture Number 65 of 2013 concerning Basic and Secondary Education Process Standards. (13) Process standards are criteria regarding the implementation of learning in educational units to achieve Graduate Competency Standards (SKL).

In line with that, the implementation of the 2013 PPKnKurriculum learning management is intended for how each education unit carries out learning planning, implementing the learning process and assessing the learning process to increase the efficiency and effectiveness of the achievement of graduate competencies.

In implementing PPKn learning, teachers are required to understand the characteristics, concepts, learning objectives, implementation strategies, basic competency maps, core competencies, topic determination and the elaboration of basic competencies into indicators that must be achieved by students. All study materials become activities. management of the implementation of PPKn learning is in accordance with the approach used in the 2013 curriculum, students are facilitated by student books, competence as an instrument to direct students to (1) quality human beings who are able and proactive to answer the challenges of the ever-changing times; (2) educated people who believe and fear the Almighty God, have noble, healthy, knowledgeable, capable, creative, independent character; and (3) democratic citizens who are responsible (Saputra, et al., 2014: iv) Teachers can enrich it with creations in 
various forms of other suitable and relevant activities that originate from the natural social environment (14)

In implementing the 2013 curriculum, teachers are required to further improve their performance. Knowledge, skills, and attitudes of educators are needed so that their implementation is in accordance with the mandate of the curriculum. For this reason, teachers need to improve their quality so that the knowledge, skills and character needed can develop in accordance with the development of teacher professionalism in implementing learning management in the implementation of the 2013 curriculum, because of the burden on The 2013 curriculum is heavier than the previous curriculum. When viewed from the element of subject position, the 2013 curriculum makes the competencies that students want to achieve, which are all derived from subjects, turned into subjects developed from competencies.

Teachers must be able to create an atmosphere of PPKn learning that is interesting, fun and exciting to students. Therefore the teacher must be able to make the subject matter not textual but must be actual. The teacher's efforts to make the actual material must be actualized so that the material is easily understood by students.

To support the actualization of the material, the teacher can use an attractive image media for students. According to Edy Suharso (2019), image media is a visual media that can only be seen, but does not have an audio or sound element. (15) According to Sadiman Arief S. (2003: 21) image media is an image related to subject matter that is useful for conveying messages from teachers to students. (16) According to the Association for Education and Communication Technology (AECT) as mentioned by Asnawir, defines media as all forms used for a process of distributing information. If the media carries messages or information that are instructional or contain teaching purposes, the media is called learning media.

Some of the characteristics of image media: Must be authentic, meaning that it can describe objects or events such as if students see directly, Simple, the composition is clear enough to show the main parts of the picture, the size of the image is proportional, so that students can easily imagine the actual size of the object or object being drawn , Combining beauty with its suitability to achieve learning objectives, Images must be a message, Not every good image is a good medium and As a good medium, images should be good from an artistic point of view and in accordance with the learning objectives to be achieved (17).

Benefits of Image Media According to Maria Sely, 2018, "explains the benefits of images as a learning medium including: Creating attraction to students. Make it easier for students to understand / understand. Make it easier to understand that is abstract in nature. Clarify andc enlarge important / small parts so that they can be observed. To abbreviate a description, information that is clarified in words may require a long description (18). Images as learning media certainly have the expected functions in the teaching and learning process, including:

a) Attention function Here, visual media or images are the core, namely attracting and directing students' attention to concentrate on the content of the lesson related to the visual meaning displayed or accompanying the text of the subject matter. For example: Images projected through the Overhead Projector can calm and direct the attention of students or learners to the lesson they will receive. Thus the possibility to obtain and remember the content of the lesson is getting bigger.

b) Affective Function Here, visual media or images can be seen from the level of enjoyment of students when learning or reading pictorial text. For example: Visual images or symbols can inspire students' emotions and attitudes, for example information concerning social or racial issues. 
c) Cognitive Function Here, visual media or images can be seen from research findings which reveal that visual symbols or images facilitate the achievement of goals to understand and remember the information or messages contained in the images.

d) Compensatory function Here the learning media can be seen from the results of research that visual media or images that provide context for understanding the text help students who are weak in reading to organize information in the text and remember it in other words, the learning media serves to accommodate students who are weak and slow to accept and understand. the content of the lesson is presented with text or presented verbally.

Based on the understanding of the concept of actualization of PPKn learning, image media and research data, it can be explained as follows. PPKn learning in a pandemic Covid 19 is carried out online, meaning that it is carried out online in each house. At SMP Negeri 1 Kartasura, the applications used are SMS, WA, contact person, video call, CP, and Google Class Room. Of the several applications that are more widely used are the WA application and contac person.

Through this application the teacher can maximize the learning outcomes of their students. Class VII students at SMP Negeri 1 Kartasura for the 2019-2020 academic year. This fact can be seen from the results of the formative tests where when the teacher does textual learning and uses the lecture method more without the support of the right media, the absorption of students is low, but after the teacher in PPKn learning with material actualization of Pancasila values using the media picture so the material is easy to understand, and high student absorption.

\section{Conclusion}

Based on the description of the results of research and discussion, it can be concluded that actualizing PPKn learning through image media is very supportive in clarifying PPKn teaching materials for grade VII students at SMP Negeri 1 Kartasura in the 2019-2020 Academic year in the pandemic covid 19. The trick is that the media images must be synchronous / in accordance with the teaching material delivered by the teacher, the media images must be colorful and varied, the media images must be actual ie in the real events.

\section{References}

[1] Sarjono (2018), Pembelajaran PPKn Kontekstual, Makalah Seminar nasional, Tidak dipublikasikan

[2] (Ahmad Johari, 2008), Teori Pembelajaran. Penerbit Universiti Teknologi Malaysia 2008 Online access, ,http://eprints.utm.my/id/eprint/10358/1/bab11.pdf ,http://eprints.utm.my/id/eprint/10358/

[3] Tanto Praptomo (2020), Pembelajaran Berbasis Permainan membangun karakter anak bangsa, jurnal Pendidikan, Volume 28 nomor 1, Maret 2019, LPPM Univet Bantara Sukoharjo

[4] Sagala, Syaiful. 2003. Konsep dan Makna Pembelajaran. Bandung: Afabeta

[5] Hamalik, 1994. Media Pendidikan. Bandung : Citra Aditya Bakti.

[6] UU Nomor 20 Tahun 2003. Pasal 1 ayat 20, Tentang Sistem Pendidikan nasional 
[7] Miarso, Yusufhadi. (2008). Menyemai Benih Teknologi Pendidikan. Cetakan Ketiga. Jakarta: Kencana Prenada Media Group.

[8] Suwarto, 2018, Implementas model pembelajaran humanis dalam pemeblajaran PPKn berbasis nilai karakter, dalam jurnal Pendidikan, Volume 29 nomor 1, Maret 2020, LPPM Univet Bantara Sukoharjo

[9] Tri Agustini, 2019, Mengganggas pembelajaran PPKn yang kreatif dan innovative dalam perspektif pendidikan karakter, dalam Jurnal, CESS, volume 2 nomor 1 , Juni 2020

[10] Sugiyono. (2016). Memahami Penelitian Kualitatif. Bandung: Alfabeta.

[11] Moleong, Lexy. J. 2016. Metodologi Penelitian Kualitatif Edisi Revisi. Bandung: PT.Remaja Rosdakarya.

[12] Saputra, 2014, Penegmbangan Materi PPKn SMP menuju Generasi Emas 2045, Dalam Jurnal CESS, Volume 1 Nomor 1 Juni 2019

[13] Mendikbud. 2013. Salinan Lampiran Peraturan Menteri Pendidikan dan Kebudayaan Republik Indonesia Nomor 65 Tahun 2013 tentang Standar Proses Pendidikan Dasar dan Menengah. Jakarta: Menteri Hukum dan Hak Asasi Manusia Republik Indonesia

[14] Online access, ,http://eprints.utm.my/id/eprint/10358/1/bab11.pdf

[15] Saputra, 2014, Penegmbangan Materi PPKn SMP menuju Generasi Emas 2045, Dalam Jurnal CESS, Volume 1 Nomor 1 Juni 2019

[16] Edy Suharso (2019), Media Pembelajaran PPKn di SMP, Sukoharjo: Usaha Mandiri

[17] Arief S. Sadiman. 2003. Media Pendidikan. Jakarta: Raja Grafindo Persada.

[18] Aristo, Rahadi. 2003,Media Pembelajaran. Jakarta : Departemen PendidikanNasional.

[19] Maria Sely, 2018, Pengembangan Media Pembelajaran PPKn Dengan Pemberdayaan lingkungan sekolah, dalam Jurnal CESS, Volume 1 Nomor 1 Juni tahun 2020 